\title{
PENGGUNAAN MODEL PEMBELAJARAN CONCEPT SENTENCE UNTUK MENINGKATKAN AKTIVITAS SISWA DAN KETERAMPILAN MENULIS KARANGAN NARASI
}

\author{
Wina Hermawati ${ }^{1}$, Anggi Citra Apriliana ${ }^{2}$ \\ 1,2STKIP Sebelas April Sumedang \\ 1'winahermawati015@gmail.com, 2anggi.citra.apriliana@gmail.com
}

\begin{abstract}
This research is motivated by the results of observations which show that the activities and writing skills of narrative essays by Grade IV students of Santaka Elementary School Cimanggung District, Sumedang Regency are still low. This is indicated by the low understanding of students in learning narrative essay writing skills and student activities that are classified as passive during learning. The purpose of this research is to improve the activities and writing skills of students' narrative essays by applying the Concept Sentence learning model. The research method used is PTK with Kemmis and Mc. Taggart. This research consisted of two cycles with 23 students. Based on the results of data analysis, it is known that the increase in student activity is seen from the average pre-cycle learning outcomes reaching 39\%, then increasing in the first cycle after using the Concept Sentence model with an average of $70 \%$ and the second cycle reaching $83 \%$. This shows an increase in student activity in learning to write narrative essays. The narrative essay writing skills in the initial conditions reached $26 \%$, then increased in the first cycle with an average of $65 \%$ and in the second cycle reached $87 \%$. This shows that the students' narrative essay writing skills have increased in each cycle with the application of the Concept Sentence model.
\end{abstract}

Keywords: Sentence Concept Model, Writing Skills, Narrative Essay

\begin{abstract}
ABSTRAK
Penelitian ini dilatarbelakangi oleh hasil observasi yang menunjukkan bahwa aktivitas dan keterampilan menulis karangan narasi siswa kelas IV SDN Santaka Kecamatan Cimanggung Kabupaten Sumedang masih rendah. Hal ini ditunjukkan dengan rendahnya pemahaman siswa dalam pembelajaran keterampilan menulis karangan narasi serta aktivitas siswa yang tergolong pasif selama pembelajaran berlangsung. Tujuan dilakukannya penelitian ini adalah untuk meningkatkan aktivitas dan keterampilan menulis karangan narasi siswa dengan penerapan model pembelajaran Concept Sentence. Metode penelitian yang digunakan yaitu PTK dengan desain Kemmis dan Mc. Taggart. Penelitian ini terdiri dari dua siklus dengan jumlah siswa sebanyak 23 orang. Berdasarkan hasil analisis data diketahui bahwa peningkatan aktivitas siswa terlihat dari rata-rata hasil pembelajaran pra siklus mencapai 39\%, kemudian meningkat pada siklus I setelah menggunakan model Concept Sentence dengan rata-rata mencapai $70 \%$ dan
\end{abstract}


siklus II mencapai $83 \%$. Hal ini menunjukkan terjadinya peningkatan aktivitas siswa dalam pembelajaran menulis karangan narasi. Keterampilan menulis karangan narasi pada kondisi awal mencapai $26 \%$, kemudian mengalami peningkatan pada siklus I dengan rata-rata mencapai $65 \%$ dan pada siklus II mencapai $87 \%$. Hal ini menunjukkan bahwa keterampilan menulis karangan narasi siswa mengalami peningkatan pada setiap siklusnya dengan penerapan model Concept Sentence.

Kata Kunci: Model Concept Sentence, Keterampilan Menulis, Karangan Narasi

\section{A. Pendahuluan}

Materi bahasa Indonesia di kelas IV salah satunya adalah menulis. Menurut pendapat Nurgiyantoro (2001: 273), "Menulis adalah aktivitas mengungkapkan gagasan melalui media bahasa". Sedangkan menurut Farris (Resmini, 2008: 221) mengemukakan bahwa, "Dalam konteks berbahasa (language art) menulis merupakan kegiatan yang paling kompleks untuk dipelajari siswa”. Khususnya di sekolah dasar, menulis merupakan keterampilan yang sulit diajarkan sehingga bagi guru, mengajarkan menulis juga merupakan tugas yang paling sulit. Dalam keterampilan menulis, penulis harus memiliki kemampuan dalam menggunakan kosakata, tata tulis,dan struktur bahasa. Dalam kegiatan menulis ini, penulis harus terampil memanfaatkan struktur bahasa dan kosakata. Keterampilan ini tidak akan datang secara otomatis, tetapi harus melalui latihan dan praktik yang banyak dan teratur.

Merujuk pendapat Yunsirno (Inggriyani dan Fazriyah, 2017) menulis adalah suatu keterampilan berbahasa yang digunakan untuk menuangkan ide atau gagasan yang ada dalam pikiran melalui bahasa tulisan sehingga dapat dibaca dan dipahami orang lain. Oleh karena itu, untuk memperoleh keterampilan menulis tidak cukup dengan mempelajari pengetahuan tentang teori menulis, melainkan tumbuh melalui proses latihan.

Salah satu keterampilan menulis yang harus dimiliki siswa kelas IV sekolah dasar yaitu keterampilan menulis narasi. Keraf (2010) membatasi pengertian narasi sebagai bentuk wacana yang sasaran utamanya adalah tindak tanduk yang dijalin serta dirangkaikan menjadi sebuah peristiwa yang terjadi dalan satu kesatuan waktu. Sedangkan 
menurut Mc Crimmon (Inggriyani dan Fazriyah, 2017) narasi merupakan sebuah kisah yang diceritakan untuk menjelaskan sesuatu ke dalam bentuk tulisan atau untuk memberikan secara rinci catatan diri pribadi mengenai yang telah terjadi. Banyak hal yang perlu diperhatikan dalam kegiatan menulis meliputi penggunaan ejaan, pemilihan kata, penyusunan kalimat, dan pembuatan paragraf.

Berdasarkan hasil penelitian mengenai karangan narasi yang telah dilakukan oleh Apriliana dan Martini (2018) terhadap siwa sekolah dasar di kecamatan sumedang selatan menunjukkan bahwa masih banyak siswa yang memiliki kesulitan dalam penggunaan ejaan pada penulisan karangan narasi. Kesalahan ejaan yang sering muncul pada siswa sekolah dasar yaitu kesalahan penulisan huruf kapital, kesalahan penulisan kata depan, dan kesalahan pemakaian tanda baca. Hal ini menandakan bahwa siswa sekolah dasar mengalami kesulitan dalam menulis narasi.

Berdasarkan observasi yang dilakukan di kelas IV SDN Santaka Kecamatan Cimanggung Kabupaten Sumedang terdapat beberapa masalah seperti siswa yang beranggapan bahwa menulis karangan narasi sangat sulit, siswa yang merasa bosan dengan pembelajaran mengenai keterampilan menulis. Tidak sedikit juga siswa yang kurang memahami isi pembelajaran terutama masalah mata pelajaran bahasa Indonesia mengenai mengungkapkan pikiran, perasaan, informasi, dan pengalaman secara tertulis dalam bentuk karangan, dan hanya sedikit siswa yang mampu mengikuti proses pembelajaran dengan baik.

Kurangnya inovasi dalam menyampaikan pembelajaran bahasa Indonesia terutama dalam keterampilan menulis menjadi masalah umum yang harus dihadapi guru agar pembelajaran menjadi efektif. Bukan hanya siswa yang mengalami kesulitan untuk menulis, melainkan guru juga mengalami kesulitan dalam mengajari siswa menulis. Guru merasa tidak maksimal dalam menyampaikan pembelajaran menulis karena sebagian besar siswa yang berada di dalam kelas tidak antusias dan cenderung menganggap dirinya tidak pandai menulis.

Berdasarkan hasil wawancara dengan wali kelas IV, siswa masih 
kesulitan untuk menulis karangan narasi, karena harus mengingat peristiwa secara runtut dan berimajinasi sesuai dengan alur cerita agar cerita dapat dimengerti secara jelas. Dapat dilihat dari Kriteria Ketuntasan Minimal (KKM) pada mata pelajaran bahasa Indonesia yaitu 70, yang mendapatkan nilai di atas KKM hanya 6 orang siswa atau $26 \%$ dan 17 orang siswa atau $73,9 \%$ yang mendapatkan nilai di bawah KKM, dari jumlah siswa sebanyak 23 orang. Hal ini membuktikan rendahnya aktivitas pembelajaran dan keterampilan menulis siswa kelas IV SDN Santaka Kecamatan Cimanggung Kabupaten Sumedang dalam pelajaran bahasa untuk indikator "Menulis karangan Narasi".

Kesulitan siswa dalam menulis karangan narasi tersebut merupakan tugas besar bagi seorang guru, yaitu dengan memperbaiki proses belajar mengajar dengan menggunakan metode pembelajaran yang tepat. Pemilihan metode pembelajaran harus didasarkan pada pertimbangan menempatkan siswa sebagai subjek belajar yang tidak hanya menerima secara pasif apa yang telah diberikan oleh guru saja. Guru harus menempatkan siswa sebagai insan yang secara alami memiliki pengalaman, keinginan, pikiran dan pengetahuan yang dapat berfungsi untuk belajar, baik secara individu maupun secara kelompok. Model yang dipilih oleh guru hendaknya dapat membuat siswa memiliki keyakinan dalam dirinya, mampu belajar dan memanfaatkan potensi seluas-luasnya.

Dari permasalahan di atas, peneliti mengambil satu permasalahan yang mungkin untuk diteliti, yaitu kesulitan anak dalam mengungkapkan pikiran, perasaan, dan pengalaman secara tertulis dalam bentuk karangan. Untuk mengatasi hal tersebut, perlu diupayakan bentuk pembelajaran keterampilan menulis yang lebih mengaktifkan siswa, yakni pembelajaran dengan menggunakan model yang dapat digunakan guru dalam pembelajaran keterampilan menulis karangan narasi adalah model pembelajaran" Concept Sentence".

Menurut Huda (2013: 315) mengemukakan bahwa, Concept Sentence yaitu suatu model pembelajaran yang berusaha mengajarkan siswa untuk menyusun kalimat dengan menggunakan 
beberapa kata kunci yang sudah disiapkan supaya bisa menangkap konsep yang terdapat dalam kalimat tersebut dan membedakannya dengan kalimat-kalimat yang lain. Secara lebih rinci, Concept Sentence yakni suatu strategi pembelajaran yang dilaksanakan dengan memberikan kartu-kartu yang berisi beberapa kata kunci kepada siswa, yang selanjutnya kata kunci-kata kunci tersebut dibuat menjadi kalimat lalu kalimat tersebut dikembangkan menjadi paragraf-paragraf yang padu.

Bruner (Huda 2013 : 315) berpendapat bahwa, Concept Sentence pada hakikatnya merupakan pengembangan dari concept attaiment yang dikembangkan dari pakar psikologi kognitif. Inti dari Concept Attaiment adalah bagaimana siswa mampu mencari dan mendaftar atribut-atribut yang dapat digunakan untuk membedakan contoh-contoh yang tepat dari yang tidak tepat. Esensi Concept Attaiment pada hakikatnya tidak berbeda jauh dengan Concept Sentence di mana pembelajaran ini berusaha mengajarkan siswa untuk membuat sebuah kalimat dengan beberapa kata kunci yang telah disediakan agar bisa menangkap konsep yang terkandung dalam kalimat tersebut dan memebedakannya dengan kalimatkalimat lain.

Dalam praktiknya, Concept Sentence merupakan model pembelajaran yang dilakukan dengan memberikan kartu-kartu yang berisi beberapa kata kunci kepada siswa, kemudian kata kunci-kata tersebut disusun menjadi beberapa kalimat dan dikembangkan menjadi paragrafparagraf. Model ini dilakukan dengan mengelompokan siswa secara heterogen dan meminta mereka untuk membuat kalimat dengan minimal 4 kata kunci sesuai materi yang disajikan.

Model pembelajaran Concept Sentence ini diharapkan dapat membantu siswa dalam memfungsikan potensi kedua belah otaknya. Adanya kartu-kartu yang berisi kata kunci untuk menulis karangan akan meningkatkan gairah serta kreativitas siswa untuk dapat menulis karangan narasi dengan baik dan benar. Terbiasanya siswa menerapkan serta memfungsikan potensi kedua belah otaknya, akan dicapai peningkatan pada berbagai aspek, di antaranya semangat, kreativitas, pemahaman, kronologi 
sehingga

siswa

dapat

mengekspresikan tulisannya dengan menerapkan model pembelajaran Concept Sentence.

\section{Berdasarkan}

identifikasi

masalah di atas, ,maka tujuan penelitian ini yaitu untuk mendeskripsikan

secara

komprehensif mengenai peningkatan aktivitas pelaksanaan pembelajaran dan peningkatan hasil keterampilan menulis karangan narasi siswa kelas IV sekolah dasar melalui Model Concept Sentence.

\section{B. Metode Penelitian}

Metode penelitian yang digunakan adalah Penelitian Tindakan Kelas (Classroom Action Research). Penelitian tindakan kelas adalah penelitian yang dilakukan oleh guru yang sekaligus sebagai peneliti sejak disusunnya suatu perencanaan sampai dengan penilaian terhadap tindakan nyata di dalam kelas yang berupa kegiatan belajar mengajar untuk memperbaiki kondisi pembelajaran yang dilakukan. Hal ini sesuai dengan tujuan PTK yaitu "Merupakan salah satu upaya yang dapat dilakukan oleh guru untuk meningkatkan kualitas peran dan tanggung jawab guru khususnya dalam pengelolaan pembelajaran" (Sanjaya, 2013: 13).

Desain PTK yang digunakan dalam penelitian ini adalah desain spiral yang di kembangkan oleh Kemmis dan Mc. Taggart. Kemis dan Taggart (Arikunto, 2009: 16) mengemukakan bahwa, "penelitian tindakan dapat dipandang sebagai siklus spiral dari penyusunan perencanaan (planning), pelaksanaan (acting), pengamatan (observasing), dan reflektif (reflecting) yang selanjutnya mungkin akan diikuti dengan siklus spiral berikutnya.

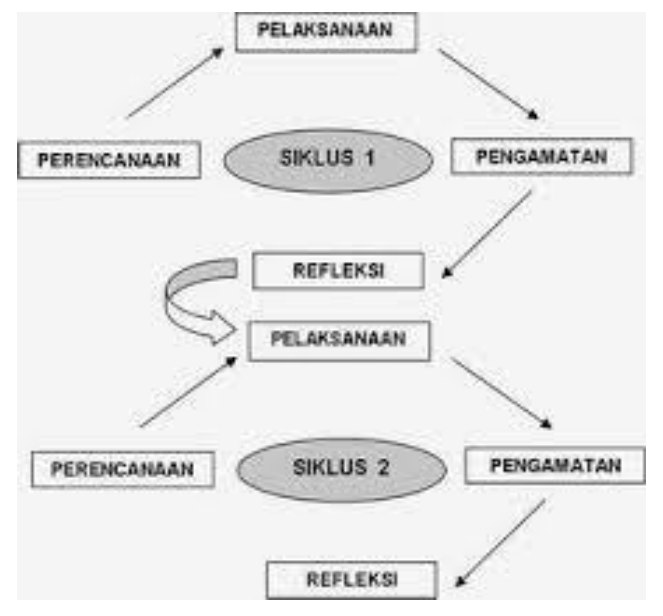

Gambar 1

Desain PTK Kemmis dan MC.Taggart (Mulyati, 2015: 89)

C.Hasil Penelitian dan

Pembahasan

\section{Hasil Aktivitas Belajar Siswa}

Berdasarkan pengamatan terhadap aktivitas siswa, tampak bahwa keaktifan, kedisiplinan, dan 
kerja sama siswa dalam mengikuti proses pembelajaran mengalami peningkatan. Berikut tabel hasil observasi peningkatan aktivitas siswa dari siklus I ke siklus II.

Tabel 1 Rekapitulasi Data Obervasi

Aktivitas Siswa dalam Proses

Pembelajaran dengan Menggunakan Model Concept Sentence

\begin{tabular}{ccccc}
\hline \multirow{2}{*}{$\begin{array}{c}\text { Keteran } \\
\text { gan }\end{array}$} & \multicolumn{2}{c}{ Tuntas } & \multicolumn{2}{c}{ Belum Tuntas } \\
\cline { 2 - 5 } ah & $\begin{array}{c}\text { Present } \\
\text { ase }\end{array}$ & $\begin{array}{c}\text { Juml } \\
\text { ah }\end{array}$ & $\begin{array}{c}\text { Present } \\
\text { ase }\end{array}$ \\
\hline $\begin{array}{c}\text { Data } \\
\text { Awal }\end{array}$ & 9 & $39 \%$ & 14 & $61 \%$ \\
\hline Siklus I & 16 & $70 \%$ & 7 & $30 \%$ \\
\hline Siklus II & 19 & $83 \%$ & 4 & $17 \%$ \\
\hline
\end{tabular}

Berdasarkan data di atas, aktivitas siswa pada siklus I hanya mencapai ketuntasan sebesar $70 \%$ dengan kriteria presentase cukup. Tetapi pada hasil observasi siklus II telah dilakukan perbaikan dan mendapat hasil yang baik yaitu seluruh siswa aktif selama pembelajaran dengan ketuntasan sebesar $83 \%$ dengan kriteria presentase baik. Selengkapnya hasil rata-rata peningkatan aktivitas siswa dapat dilihat pada gambar grafik di bawah ini.

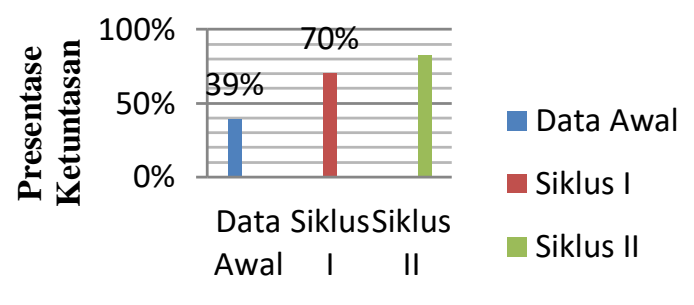

Hasil Observasi Aktivitas Siswa

Gambar.1 Peningkatan Aktivitas

Siswa

Berdasarkan grafik di atas, peningkatan aktivitas siswa kelas IV SDN Santaka Kecamatan Cimanggung Kabupaten Sumedang terlihat peningkatan yang sangat baik. Peningkatan ini terjadi karena penggunaan model Concept Sentence membuat aktivitas belajar siswa meningkat dan menuntut siswa untuk aktif dalam melakukan pembelajaran menulis karangan narasi.

Model Concept Sentence termasuk salah satu model yang dapat digunakan dalam pembelajaran menulis karangan narasi, karena model Concept Sentence dapat membuat siswa menjadi kreatif dalam mengembangkannya menjadi sebuah cerita karangan narasi berdasarkan pengalaman pribadi ini sejalan dengan pendapat Taylor (Huda, 2013: 303) mengemukakan bahwa, "Model Concept Sentence menuntut 
siswa mampu menjawab soal dengan disediakannya kata kunci sehingga mampu meningkatkan aktivitas belajar siswa dikelas".

Setelah selesai memberikan penjelasan, siswa semakin aktif bertanya kepada guru dan saling tukar pendapat kepada sesama teman. Setelah terlihat adanya peningkatan terhadap peningkatan aktivitas siswa ini, guru melakukan kegiatan yang dapat mempertahankan keaktifan siswa selama pembelajaran. Senada dengan pendapat Soeparno (1998: 60), Model Concept Sentence merupakan permainan bahasa, karena pada hakikatnya permainan bahasa merupakan suatu aktivitas untuk memperoleh keterampilan tertentu dengan cara menggembirakan sehingga mampu meningkatkan aktivitas belajar siswa”.

Menurut Suyatno (2009: 76), "Dalam model Concept Sentence setiap siswa tidak ada yang diam karena setiap individu di kelompok diberi tanggung jawab akan keberhasilan kelompoknya, sehingga setiap siswa dituntut untuk aktif dalam pembelajaran". Pada saat dilakukan pembelajaran siklus I, terdapat beberapa siswa yang belum tertarik dan belum aktif saat belajar, terbukti dengan adanya siswa yang belum sepenuhnya memperhatikan guru dalam menjelaskan materi. Karena siswa belum memperhatikan dengan baik, maka hal ini tentunya berpengaruh pada hasil belajar siswa nantinya.

Kemudian saat guru melakukan perbaikan pada siklus II, terdapat peningkatan aktivitas siswa yang sangat baik kearah yang lebih positif. Pada saat pembelajaran siswa sangat memperhatikan dan sangat tertarik ketika guru membagi kelompok terbukti denga adanya presentase ketuntasan siswa sebesar $83 \%$ dengan kriteria baik.

Pada aktivitas siswa selama proses pembelajaran menulis karangan narasi dengan menggunakan model Concept Sentence, siswa dituntut untuk lebih aktif sesuai dengan model yang diterapkan. Model Concept Sentence tidak hanya menuntut guru untuk lebih aktif, tetapi siswa juga dituntut untuk lebih aktif dan kreatif agar pembelajaran berjalan 45ancer sesuai dengan tahap perencanaan. Model Concept Sentence menuntut siswa untuk lebih aktif dalam berpikir karena harus menyusun kalimat 
menggunakan media kartu kata menjadi kalimat yang utuh dan benar.

\section{Hasil Keterampilan Menulis}

\section{Karangan Narasi Siswa}

Berdasarkan hasil penelitian siklus I dan siklus II yang dilakukan mengenai hasil belajar siswa dalam pembelajaran menulis karangan narasi dengan menggunakan model Concept Sentence di kelas IV SDN Santaka Kecamatan Cimanggung Kabupaten Sumedang tahun pelajaran 2018/2019, diperoleh hasil sebagai berikut.

Tabel 2. Rekapitulasi Ketuntasan Hasil Keterampilan Menulis Karangan Narasi Siswa Tiap Siklus dengan Menggunakan Model Concept Sentence

\begin{tabular}{ccccc}
\hline \multirow{2}{*}{$\begin{array}{c}\text { Keteran } \\
\text { gan }\end{array}$} & \multicolumn{2}{c}{ Tuntas } & \multicolumn{2}{c}{ Belum Tuntas } \\
\cline { 2 - 5 } ah & $\begin{array}{c}\text { Present } \\
\text { ase }\end{array}$ & $\begin{array}{c}\text { Juml } \\
\text { ah }\end{array}$ & $\begin{array}{c}\text { Present } \\
\text { ase }\end{array}$ \\
\hline $\begin{array}{c}\text { Data } \\
\text { Awal }\end{array}$ & 6 & $26 \%$ & 17 & $74 \%$ \\
\hline Siklus I & 15 & $65 \%$ & 8 & $35 \%$ \\
\hline Siklus II & 20 & $87 \%$ & 3 & $13 \%$ \\
\hline
\end{tabular}

Berdasarkan pengolahan hasil belajar siswa yang telah dikumpulkan peneliti, dapat dilihat bahwa peningkatan hasil belajar bahasa Indonesia dalam menulis karangan narasi meningkat dengan peningkatan yang baik. Berdasarkan data awal yang diperoleh, jumlah siswa yang mencapai KKM hanya 6 orang, siklus I meningkat menjadi 15 orang siswa, dan siklus II meningkat sebanyak 20 orang siswa.

Untuk mengetahui peningkatan hasil belajar bahasa Indonesia dalam pembelajaran menulis karangan narasi dengan menggunakan model Concept Sentence di kelas IV SDN Santaka Kecamatan Cimanggung Kabupaten Sumedang tahun pelajaran 2018/2019 dapat digambarkan dalam grafik berikut.

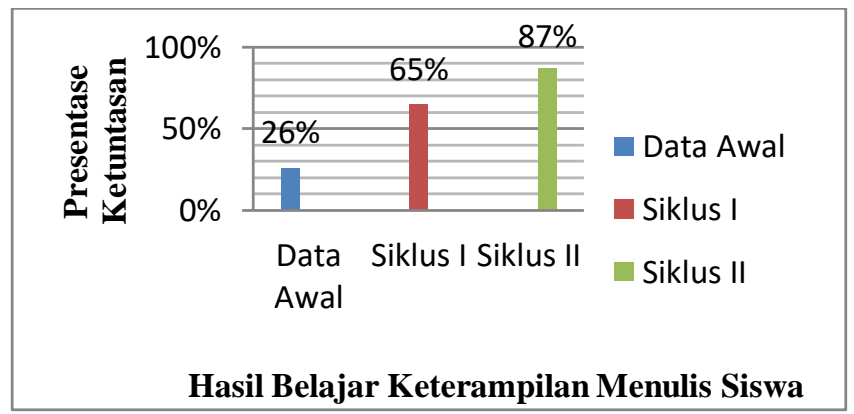

\section{Gambar 2. Peningkatan Hasil Belajar Keterampilan Menulis Siswa}

Berdasarkan gambar di atas, pada pembelajaran siklus II mendapatkan hasil belajar yang sangat baik, yaitu $87 \%$ siswa mengalami peningkatan dan berhasil mencapai KKM. Setelah dilakukan perbaikan pada siklus II, pemahaman siswa menjadi meningkat dan tidak kesulitan lagi dalam menulis karangan narasi.

Peningkatan hasil belajar siswa dapat dilihat dari hasil belajar siswa dan cara siswa dalam mengerjakan tugas di kelas. Hasil belajar siswa 
dalam pembelajaran menulis karangan narasi meningkat setelah dilakukan tindakan dengan menggunakan model Concept Sentence pada pembelajaran menulis karangan narasi. Model Concept Sentence ini mampu melatih keterampilan menulis siswa dan dapat meningkatkan kosentrasi dan kecepatan berpikir siswa dalam pembelajaran menulis karangan narasi sehingga mampu meningkatkan hasil belajar siswa yang signifikan.

Dengan menggunakan model Concept Sentence, pembelajaran menjadi lebih menarik dan tidak terkesan monoton dan membuat siswa bosan ini sejalan dengan pendapat Suyatno (Murti dkk, 2016), "Model Concept Sentence menuntut siswa untuk berfikir kreatif dalam pembelajaran di dalam kelas, sehingga mampu meningkatkan hasil pembelajaran dalam menulis karangan narasi”. Sedangkan menurut Taylor (Huda, 2013: 303), "Dalam model Concept Sentence siswa mampu meningkatkan kosentrasi dan kecepatan berpikir siswa, sehingga siswa mampu mengingat pengalaman pribadinya dan menuangkan setiap ide gagasan ke dalam sebuah cerita dalam bentuk narasi”. Menurut Soeparno (1998: 60), "Melalui model Concept Sentence siswa mampu menyusun wacana dengan susunan yang bermakna dalam menulis karangan narasi".

Berdasarkan hasil observasi dan temuan yang ditemukan peneliti telah dipaparkan tiap siklus dan kesesuaian pelaksanaan tindakan dengan pendapat para ahli di atas, menunjukkan bahwa penggunaan model Concept Sentence dapat meningkatkan keterampilan menulis siswa pada mata pelajaran bahasa Indonesia di kelas IV SDN Santaka Kecamatan Cimanggung Kabupaten Sumedang pada materi menulis karangan narasi.

\section{E. Kesimpulan}

Berdasarkan penelitian yang telah dilakukan penulis, secara umum dapat dijelaskan bahwa penerapan model Concept Sentence untuk materi keterampilan menulis karangan narasi siswa kelas IV SDN Santaka Kecamatan Cimanggung Kabupaten Sumedang Tahun Pelajaran 2018/2019 dapat meningkatkan aktivitas dan keterampilan menulis karangan 
narasi. Peningkatan aktivitas dan keterampilan menulis karangan narasi tersebut dapat diuraikan sebagai berikut.

1. Penerapan model Concept Sentence dapat meningkatkan aktivitas siswa kelas IV SDN Santaka pada setiap siklusnya. Peningkatan aktivitas menulis karangan narasi dapat dilihat dari kondisi awal dengan presentase mencapai 39\%, pada siklus । mencapai 70\%, dan siklus II mencapai 83\%. Dari kondisi awal sampai siklus II, aktivitas keterampilan menulis karangan narasi siswa terus mengalami peningkatan sehingga penelitian yang dilakukan selesai di siklus II karena hasil siklus II sudah sesuai apa dengan yang diharapkan.

2. Penerapan model Concept Sentence dapat meningkatkan keterampilan menulis karangan narasi siwa kelas IV SDN Santaka. Peningkatan tersebut dapat dilihat dari data awal yang mencapai 26\%, keterampilan menulis karangan narasi pada siklus I mencapai $65 \%$ dan siklus II mencapai $87 \%$. Dari data hasil analisis tersebut menunjukkan bahwa terjadi peningkatan keterampilan menulis karangan narasi siswa dengan menerapkan model Concept Sentence pada setiap pembelajaran.

\section{DAFTAR PUSTAKA}

Apriliana dan Martini. (2018). Analisis Kesalahan Ejaan dalam Karangan Narasi pada Siswa Kelas V Sekolah Dasar Kecamatan Sumedang Selatan. PRIMARY, 7(2) , 227232.

Arikunto, S. (2009). Prosedur Penelitian Suatu Pendekatan Praktik. Edisi Revisi 6. Jakarta: Rineka Cipta.

Huda, M. (2013). Model-model Pengajaran Dan

Pembelajaran. Yogyakarta: Pustaka Pelajar. Inggriyani, F., \& Fazriyah, N. (2017). Pengaruh Berpikir Kritis Terhadap Kemampuan Menulis Narasi Siswa Kelas IV Di Sekolah Dasar. JPSD, 3(2), 105-116.

Kerap, Gorys. (2010). Argumentasi dan Narasi. Jakarta: Gramedia

Mulyati.M. (2015). Upaya Meningkatkan Kemampuan 
Penalaran Matematis Siswa melalui Model Kooperatif Tipe Somatic, Auditory, Visualization, Intelectually (SAVI). Skripsi pada Universitas UNINUS: tidak diterbitkan.

Murti, I Gede Ari dkk. (2016). Pengaruh Model Pembelajaran Concept Sentence Berbantuan Media Gambar Terhadap Hasil Belajar Siswa Kelas IV SDN Teluk. Dalam e-Jurnal PGSD Universitas Pendidikan Ganesha Jurnal PGSD [Online], Vol 9 (1), 11 halaman. [25 Januari 2019].

Nurgiyantoro, B. (2001). Penilaian dan Pengajaran Bahasa dan Sastra. Yogyakarta: BPFE.

Resmini, Novi., dkk. (2008).

Membaca dan Menulis di SD:

Teori dan Pengajarannya.

Bandung: UPI PRESS.

Sanjaya, W. (2013). Penelitian

Pendidikan, Jenis, Metode dan

Prosedur. Jakarta: Kencana

Prenada Media Group.

Soeparno. (1998). Media Pengajaran

Bahasa. Klaten: Intan Pariwara.

Suyatno. (2009). Menjelajah

Pembelajaran Inovatif. Sidoarjo:

Masmedia Buana. 